\title{
Description of a new subspecies Diastylis enigmatica rossensis (Crustacea: Peracarida: Cumacea) from the Ross Sea, Antarctica
}

\author{
Peter Rehm
}

Received: 2 October 2007 / Revised: 21 July 2008 / Accepted: 6 October 2008 / Published online: 7 November 2008

(C) Springer-Verlag and AWI 2008

\begin{abstract}
Diastylis enigmatica rossensis $\mathrm{n}$. $\mathrm{ssp}$. is described and illustrated on the basis of new specimens from the Antarctic shelf in the Ross Sea. The material was collected off the Victoria Land coast during the 19th Antarctic expedition of the Italian research vessel Italica in 2004. Diastylis enigmatica Ledoyer, 1993 was first obtained during the EPOS 3 campaign at Halley Bay in the Weddell Sea. A redescription based on further material from the Weddell Sea was published by Petrescu and Wittmann (Zool Med Leiden 77:557-630, 2003), which shows several differences to the newly collected material from the Ross Sea. The most obvious differences from Diastylis enigmatica rossensis n. ssp. to Diastylis enigmatica enigmatica Ledoyer, 2003 are the absence of four spines on the merus of the second pereiopod, a lower number of setae on the uropodal endopod, a gap between spines on the peduncle article 1 of antenna 1 , and a higher number of articles in both flagella of antenna 1 .
\end{abstract}

Keywords Antarctica C Crustacea C Cumacea .

Diastylidae $\cdot$ Ross Sea $\cdot$ Victoria Land

\section{Introduction}

Diastylis enigmatica Ledoyer, 1993 was first described from material collected during the EPOS 3 campaign

Communicated by P. Funch.

P. Rehm $(\varangle)$

Animal Physiology, Universität Hamburg,

Biozentrum Grindel, Martin-Luther-King-Platz 3,

20146 Hamburg, Germany

e-mail: peter.rehm@awi.de
(Arntz et al. 1990) at Halley Bay in the Weddell Sea. The original description is based on a juvenile male with incomplete uropods, which was found between 270 and $280 \mathrm{~m}$ water depth. In 1989/1990, five further specimens were found at a depth between 240 and $260 \mathrm{~m}$ during the Expedition Antarktis-VIII/5 with RV Polarstern. Based on this material Petrescu and Wittmann (2003) redescribed a subadult female of Diastylis enigmatica. Additional specimens from the Antarctic shelf in the Ross Sea (216-366 m) were obtained off the Victoria Land coast during the 19th Antarctic expedition of the Italian research vessel Italica in 2004 (Rehm et al. 2007). A first examination of the material from the Italica cruise already showed slight differences in some of the cumacean species to the original descriptions. With the present study the description of a marsupial female of the new subspecies Diastylis enigmatica rossensis and a detailed analysis of sexual and developmental differences in the subspecies of Diastylis enigmatica is provided.

\section{Materials and methods}

Material for this study was collected during the 19th Antarctic expedition of RV "Italica" to the Ross Sea (Rehm et al. 2006). In total 173 specimens were sampled at four stations and examined with a Leica MZ12 ${ }_{5}$ and an Olympus SZX12 dissecting microscope with camera (Olympus Colour View I). Dissected appendages were mounted on slides in glycerine and studied with a Zeiss AxioSkop 1 with attached camera (Olympus DP70). Drawings were created from digital photographs using a digital drawing tablet (Wacom Intous3 $9 \times 12$ ) as described by Coleman (2003, 2006). Material has been deposited in the collection of the Zoological Museum Hamburg (ZMH). 
The material was collected with a Rauschert dredge (Rehm et al. 2006) along the Victoria Land coast at four stations ranging from 216 to $366 \mathrm{~m}$. For detailed data on the sampling stations and on species diversity and distribution found at these stations refer to Rehm et al. (2007).

Body length is measured from the tip of the pseudorostrum to the tip of the telson. Length of articles are measured according to Mühlenhardt-Siegel (2005) and given as relative length of peduncle (RLP) articles $1-3$ of antenna 1 compared to total peduncle length. The ratio basis to rest $(\mathrm{B} / \mathrm{R})$ is given for maxillipeds and pereiopods, which is the proportion of the basis to the combined length from ischium to dactylus, not including terminal setae. RLA refers to the relative length of each article from ischium to dactylus, excluding terminal setae.

The following types of setae were distinguished: simple setae are slender and completely lack outgrowths on the setal shaft; pappose setae have irregularly distributed setules along the shaft; plumose setae have many setules arranged in two strict opposite rows, giving the setae a feather-like appearance; serrate setae have one or two rows of denticles in their distal half; setulate-serrate setae have long setules on proximal half and one or two rows of denticles on distal half; cuspidate setae are short setae that are wide at the base; broom setae are tiny and have a pedestal and extremely thin setules distally; and annulate setae are simple and have a distinct internal spiral structure in their distal half.

\section{Results}

Order: Cumacea Kröyer, 1846

Family: Diastylidea Bate, 1856

Genus: Diastylis Say, 1818
Diastylis enigmatica rossensis $n$. ssp. (Figs. 1, 2, 3, 4, 5)

Material: was deposited in the Zoolical Museum Hamburg.

Holotype: incubating female (ZMH 42030; partially dissected); station R2 $74^{\circ} 49.0^{\prime} \mathrm{S} / 164^{\circ} 18.1^{\prime} \mathrm{E}$, fine sand, $364 \mathrm{~m}$, 21 February 2004.

Paratypes: subadult females (ZMH 41273), both specimen were dissected; same station data as holotype. Two juvenile females, a juvenile male, and a subadult male (ZMH 41274), station R3 $74^{\circ} 49.3^{\prime} \mathrm{S} / 164^{\circ} 11.5^{\prime} \mathrm{E}$, rocky sand substratum with mud and pebbles, $330 \mathrm{~m}, 20$ February 2004. Juvenile male (ZMH 41275), station SMN $74^{\circ} 43.2^{\prime} \mathrm{S} / 164^{\circ} 13.1^{\prime} \mathrm{E}, 366 \mathrm{~m}$, sand with gravel and stones, 20 February 2004.

\section{Description}

Adult female. Body length $8.9 \mathrm{~mm}$.

Carapace (Fig. 1). 1.6 times longer than high, with four denticulate transverse ridges; some very small simple setae, slightly more concentrated on frontal lobe and on anterior and ventral margin; minor denticulate ridges, with slightly varying structure on both sides of carapace. Eyelobe with two spines; six spines on frontal lobe as described in Petrescu and Wittmann (2003), further dorsal spines of varying size along three-fourths of carapace length. Pseudorostrum moderately produced about one-sixth of total carapace length (including pseudorostrum). Antennal notch shallow. Lateral medial margin serrated. Integument of segments with honeycomb-like structure; margins with fine serrations. Sternites of last three thoracic segments with median spine decreasing in length. Last pleon segment ventrally with two rows of five denticles forming a ' $v$ ' opening to the posterior end. Carapace and free thorax segments approximately 1.2 times longer than abdomen.

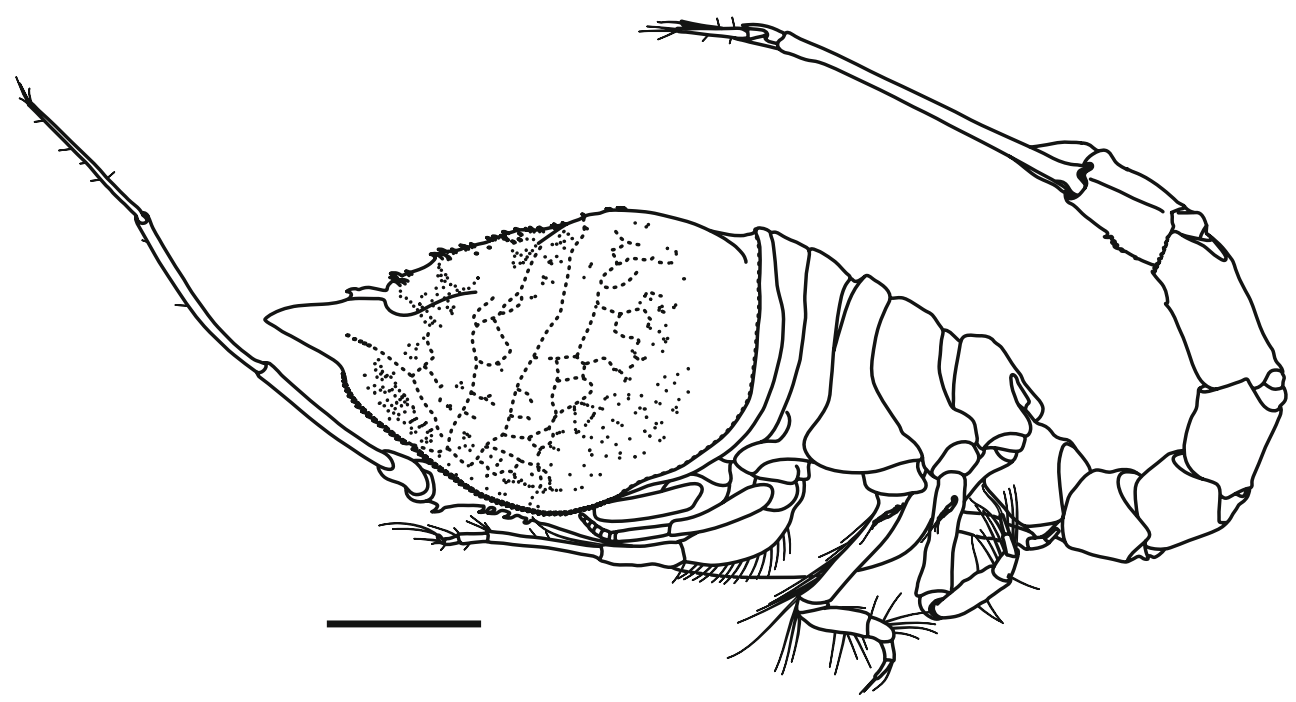

Fig. 1 Diastylis enigmatica rossensis $\mathrm{n} . \mathrm{ssp}$. adult female; (scale $1 \mathrm{~mm}$ ) 


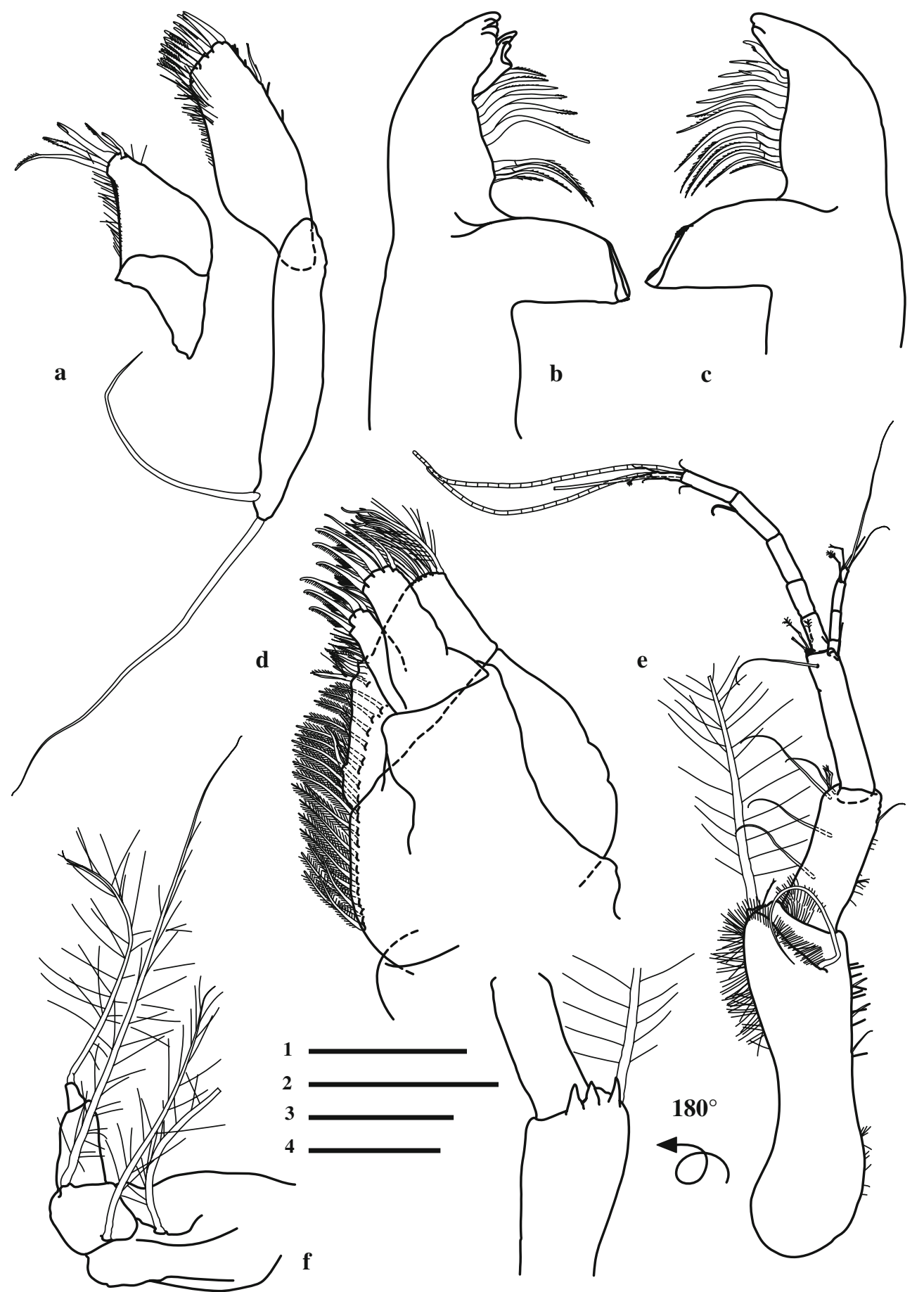

Fig. 2 Diastylis enigmatica rossensis $\mathrm{n}$. ssp. adult female; a maxilla 1, b left mandible, c right mandible, $\mathbf{d}$ maxilla 2, e antenna 1, f antenna 2 (scales $0.2 \mathrm{~mm}) ; 1=\mathbf{a} ; 2=\mathbf{d} ; 3=\mathbf{e}, \mathbf{f} ; 4=\mathbf{b}, \mathbf{c}$

Antenna 1 (RLP 54/23/23) (Fig. 2e). First article of peduncle with three spines on distal margin, one slightly separated from others, with one pappose seta and one broom seta distally, many hair-like setae, row of hair-like setae along little more than distal third of article turning back along integumental fold and ending with a simple seta; second article with few hair-like setae, proximal many hair-like setae, five simple setae and one broom seta distally; third article with a simple and three broom setae distally; main flagellum of six articles, article 4 with one simple seta, article 5 two simple setae and two aesthetascs distally, article 6 with three simple setae and a broom seta; 


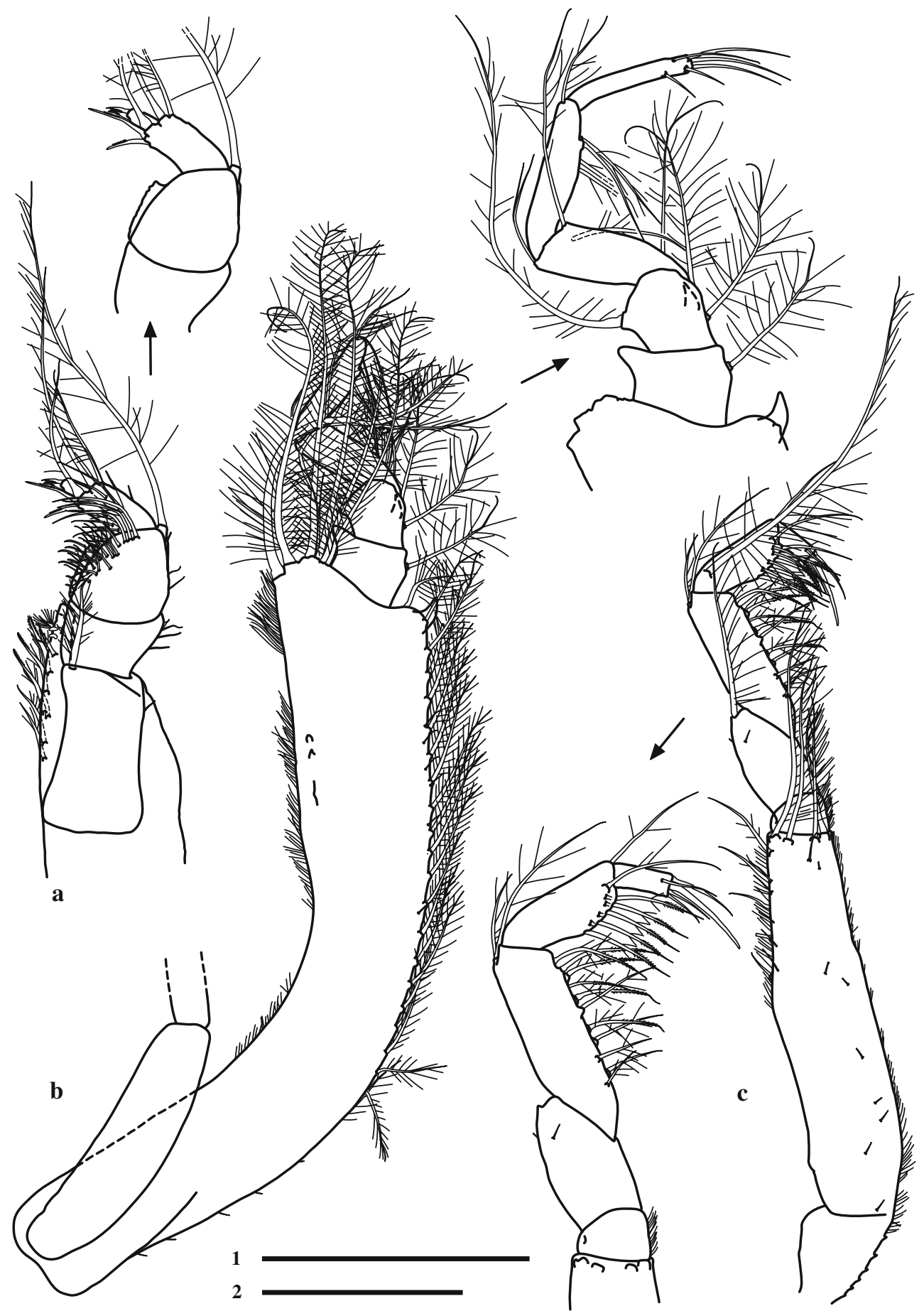

Fig. 3 Diastylis enigmatica rossensis $\mathrm{n}$. $\mathrm{ssp}$. adult female; a maxilliped 1 , b maxilliped 3 , c maxilliped $2($ scales $0.5 \mathrm{~mm} ; 1=\mathbf{a}, \mathbf{c} ; 2=\mathbf{b})$

accessory flagellum with four articles, article 1 with one seta (was broken in the specimen), third article with one broom seta, fourth article with a broom seta and three simple setae.

Antenna 2 (Fig. 2f). Four articles, first article with a pappose seta; second article with two pappose setae; fourth article bearing terminal a pappose seta.
Mandibles (Fig. 2b, c). Typical of genus; left mandible lacinia mobilis and 12 or 13 (one or two setae broken off) setae of various shapes (simple and serrate); right mandible with 13 setae of various shape (serrate and bifurcate), most distal seta trifurcate.

Maxilla 1 (Fig. 2a). Lateral endite having 14 cuspidate simple or serrate setae, single subdistal seta on lateral mar- 


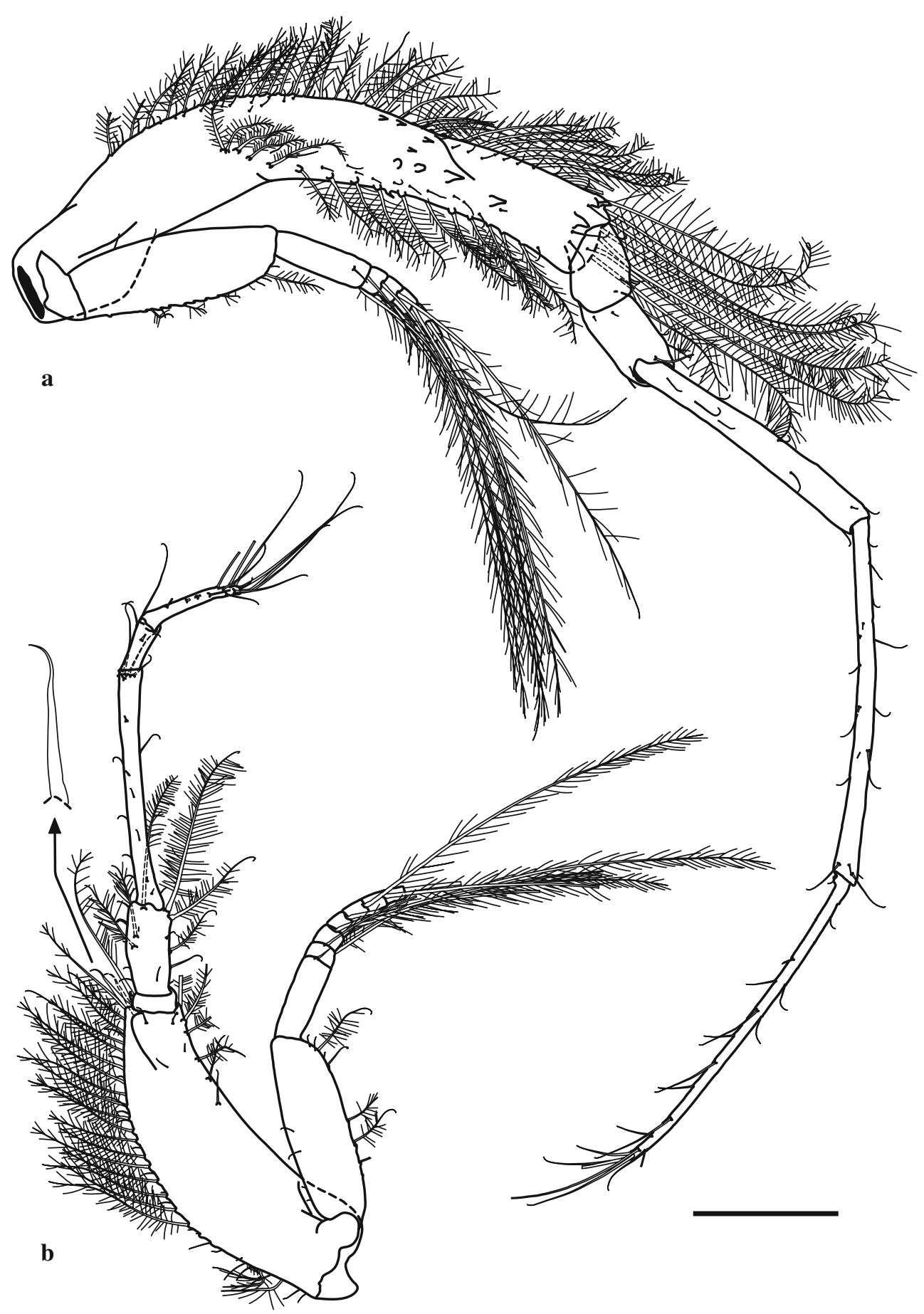

Fig. 4 Diastylis enigmatica rossensis n. ssp. adult female; a pereiopod 1, b pereiopod 2 (scale $0.5 \mathrm{~mm}$ )

gin, several hair-like setae on distal half; medial endite with three serrate setae, a bifurcate setae, and a simple seta: palp terminating in two setae with microsetules distally.

Maxilla 2 (Fig. 2d). A row of plumose setae parallel to medial edge of protopod slightly turning outward subdistally, medial edge with some hair-like setae and a serrate seta in distal third, medial distal edge with a setulate-serrate seta, distally various types and shapes of simple and serrate setae and a pappose seta at lateral edge; lateral lobe of endite with three medial serrate setae and three lateral simple setae distally; medial lobe with three medial serrate setae and one lateral simple seta distally, four simple setae distally on medial margin.

Maxilliped 1 (B/R 0.6; RLA -/27/32/30/11) (Fig. 3a). Basis with many hair-like setae (not drawn in the figure), one pappose seta at distal margin, projection of the basis 


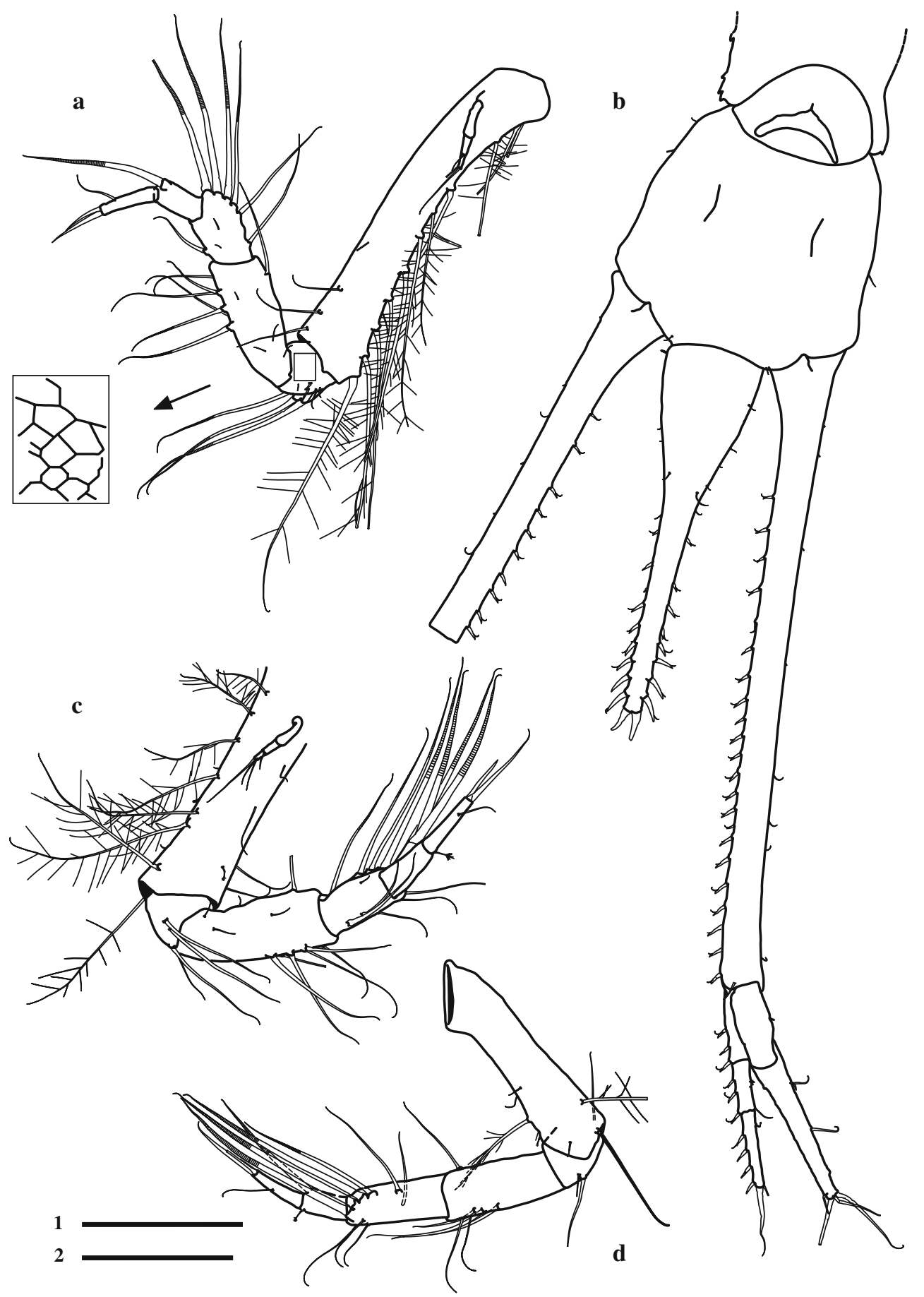

Fig. 5 Diastylis enigmatica rossensis $n$. ssp. adult female; a pereiopod 3, b uropod, c pereiopod 4, d pereiopod $5($ scale $0.5 \mathrm{~mm} ; 1=\mathbf{a}, \mathbf{c}, \mathbf{d} ; 2=\mathbf{b})$

with four pappose setae and four setulate-serrate setae at medial margin, two retinacula present, ischium absent; merus with three simple setae along distal half of lateral margin and 1 minute seta on a protuberance on lateral distal margin; carpus, medial margin with simple setae and a dense group of simple, trifurcate-pappose, and pappose setae close to medial and distal margin, medial margin with a lamelliform structure, three simple setae at lateral margin and one large pappose seta at lateral distal edge; propodus, simple and pappose setae mainly close to medial margin, three pappose setae and two serrate setae distally; dactylus with two terminal cuspidate and one serrated setae.

Maxilliped 2 (B/R 1.0; RLA 9/24/34/23/10) (Fig. 3c). Basis, eight simple and two pappose setae along distal lateral edge, hair-like setae at distal third of lateral margin and along three quarters of medial margin, four pappose setae 
distally and one simple seta subdistally; ischium, medial margin with hair-like setae; merus, lateral edge of distal margin with one pappose seta; carpus, along medial margin eleven setae (pappose and setulate-serrate), two pappose setae close to lateral distal edge; propodus having one large pappose seta proximally, eight setulate-serrate setae in distal half of medial margin, distal margin with three pappose setae; dactylus, terminal and subterminal four simple setae and one cuspidate seta.

Maxilliped 3 (B/R 1.4; RLA 14/12/24/28/22) (Fig. 3b). Basis curved, lateral margin with hair-like setation, proximal third without setation, along medial margin 20 pappose setae, medial distal edge with one pappose seta, distal lateral edge with one pappose seta and six large pappose setae, at distal third close to lateral margin 2 minute spines and a scale-like structure, one strong spine at medial distal edge (four spines in a row along medial margin in premature females); ischium, one pappose seta subdistally at medial margin, lateral margin bearing a process subdistally; merus, two pappose setae at medial margin, one large plumose setae at lateral margin, spine close to medial margin; carpus, three pappose setae, one medially, one subdistally, and one at lateral distal edge, one bifurcated seta at medial distal edge; propodus, four pappose setae at lateral margin, one pappose seta at medial distal edge; dactylus, six simple setae subterminally and terminally.

Pereiopod 1 (B/R 0.5; RLA 7/10/22/32/31) (Fig. 4a). Basis, hair-like setae along margins, four small simple setae at distal margin, a row of 16 pappose setae along lateral margin starting subdistally the position of the six proximal most setae shifting to midline of article, 45 pappose setae along medial and distal margin, small and minute simple setae along both rows of pappose setae, a row of four spines along midline, a second row of small spines in the middle of medial margin (some less developed, scale-like), a spine between seventh and eighth pappose seta of lateral margin (spine was not observed in premature females), a group of three spines at medial distal edge, separated from a larger spine in the middle of distal margin; ischium, few minute simple setae; merus, few minute simple setae, two small simple setae and two small pappose setae distally; carpus, six small simple setae along the article, three small simple setae at distal margin; propodus, 12 small simple setae along article, subdistally four simple setae; dactylus, 12 simple setae of varying size along the article, terminal and subterminal seven simple setae; exopod fully developed.

Pereiopod 2 (B/R 0.7; RLA 4/18/48/10/19) (Fig. 4b). Basis, few minute setae, 25 pappose setae along medial margin, small simple setae along medial margin, five pappose setae at distal fourth of lateral margin; one small simple setae on an elevation close to medial distal margin, one cuspidate simple seta with a tapered and curved tip (drawn with dotted lines, as it was broken off, but was observed in subadult specimens of both sexes) at distal end of elevation, a second cuspidate seta of that morphology at medial distal margin (see enlargement), close to lateral distal margin one broom seta; ischium, small without setation, spine on medial margin; merus, some small and minute simple setae, lateral margin with one simple and one pappose seta, close to medial margin two pappose seta, distal edge with three pappose seta; carpus, some simple seta of varying size along article, distally five simple setae of varying size; propodus, medial margin distally with one simple seta and one small simple seta, one broken seta subdistally; dactylus, four seta along article (broken), distally nine simple setae of varying size.

Pereiopod 3 (B/R 1.0; RLA 15/36/21/12/15) (Fig. 5a). Basis, 11 pappose setae along medial margin, close to lateral margin in distal half three simple setae and one broken seta, integument of distal and proximal margin with honeycomb-like structure (not drawn, compare Fig. 5a); ischium, five small simple setae close to medial margin, three large annulated setae at medial margin, integument with honeycomb-like structure (partially drawn only; Fig. 5a); merus, four simple setae and two annulated setae at medial margin, one simple seta at lateral margin, four small simple setae; carpus; one simple seta at medial margin, two simple setae at lateral margin, lateral distal margin with four long and strong annulated setae; propodus, lateral distal margin with one strong annulated seta; dactylus, one simple seta and two cuspidate terminal setae; exopod, poorly developed with three articles, second articulation with one simple setae, third articulation terminating with two simple setae.

Pereiopod 4 (B/R?; RLA 14/39/17/14/16) (Fig. 5c). Basis (not completely preserved), few minute simple setae, a row of seven pappose setae increasing in size to distal lateral margin, two simple seta and one broom seta at medial margin, one broom and one pappose seta at distal margin, distal margin with honeycomb-like structure (compare Fig. 5a); ischium, four simple setae, integument with a honeycomb-like structure (compare Fig. 5a); merus, six simple setae on lateral distal margin, one simple seta on medial margin, few minute setae; carpus, three simple setae at distal half of lateral margin, two annulated setae at proximal half of lateral margin, six annulated setae along medial and distal margin, propodus, one strong annulated seta at medial margin and broom seta distally; dactylus, one simple seta, terminally one simple seta and one cuspidate seta; exopod, poorly developed with three articulations, second articulation with one simple seta, third articulation terminating with three simple setae.

Pereiopod 5 (B/R 0.5; RLA 16/31/26/12/15) (Fig. 5d). Basis, few minute setae; lateral and medial margin with one pappose seta each, two simple setae at medial distal margin, lateral distal edge and distal margin with one broom seta, honeycomb-like structure at distal and proximal margin 
(compare Fig. 5a); ischium, medial distal margin with one small simple and one simple seta, integument with honeycomb-like structure (compare Fig. 5a); merus, distally one simple seta at lateral margin, five simple setae in distal half of medial margin; carpus, a row of four annulated setae close to lateral distal margin, three of which are strong, two simple setae, three simple setae at medial distal margin; propodus, medial distal margin with one broom seta, lateral distal margin with one strong annulated seta; dactylus, with one simple seta and terminally two simple setae, one of which is strong; exopod, absent.

Uropod (Fig. 5b). All cuspidate setae with a setule; peduncle, three times longer than endopod, medial margin of peduncle with 22 short cuspidate setae, one small simple seta at distal margin, endopod triarticulate, medial margin of first article with three short cuspidate setae, medial margin of second article with four short cuspidate setae, lateral margin of second article with two broom setae and one simple seta distally, medial margin of third article with four short cuspidate setae, lateral margin of third article with one broom seta, terminal with one small simple seta and one strong seta with a terminal filament; exopod, 1.2 times longer than endopod, lateral margin with two small simple setae and 2 minute simple setae, subterminal one small simple seta and three terminal simple setae.

Telson. 0.6 times length of peduncle, some small and minute simple setae on broader proximal part of telson, eight short cuspidate setae with filament on both sides of distal part, enlarging to distal end, two distal cuspidate setae.

Subadult males. Second antenna incompletely developed and lacking articulation and setae, reaching posteriorly to abdomen. Median row of spines of pereiopod 1 comprising about 15 spines; medial margin with six spines more developed than in female. Basis of maxilliped three with five spines along medial distal margin, instead of four as in the adult female. Exopods developing on maxilliped 3 and on pereiopods $1-4$. Articles 2 of the uropodal endopod bearing four cuspidate setae with filament, instead of three as in the adult female. Pleopod buds present on abdominal segments 1 and 2, with 3 or 4 minute setae distally.

Juvenile males. The exopod of the third pereiopod is only biarticulate, whereas it is triarticulate in juvenile females.

\section{Discussion}

\section{Subspecies of Diastylis enigmatica}

In all specimens of the present study the ratio of telson length versus uropodal peduncle was 0.6 , as described by
Petrescu and Wittmann (2003). In the description of Ledoyer (1993) the exopod of the third pereiopod has two segments, whereas in Petrescu and Wittmann the exopod is three-segmented. During the present study it was possible to explain this variation by sexual dimorphism, as juvenile males were collected, which have two-segmented exopods, whereas the exopods of juvenile females are three-segmented. From the number of segments and the large size of the exopod, the specimen of Ledoyer must have been a juvenile male. In Petrescu and Wittmann the length of the postanal part of the telson from Ledoyer's description is mentioned as being smaller than the preanal part. In the original drawing, both parts seem to be equal in length (in the text Ledoyer described the telson as being even three times longer than the preanal part). The ratio of postanal to preanal part of telson (Table 1) varied from 1.2 to 1.9 in the present study. The ratio in the specimens from the Weddell Sea material seems to be lower than in the same developmental stages from the Ross Sea. However, the ratios from the Weddell Sea are not precise enough to use this character to differentiate both subspecies.

Presently, two subspecies of Diastylis enigmatica are distinguished according to differences found from the description of Petrescu and Wittmann (2003) to the material of the Ross Sea (Table 1). Due to obscure or contradicting morphological characters of the first description of Diastylis enigmatica (Ledoyer 1993) it is impossible to assign it to one of the subspecies. This problem can be addressed in the future, when further material from the type locality (Weddell Sea), including adult males and females, is available. Nevertheless, the geographical distribution supports the assumption that both descriptions from the Weddell Sea refer to the same subspecies Diastylis enigmatica enigmatica Ledoyer, 1993. The second subspecies, Diastylis enigmatica rossensis n. ssp., was found only in the Ross Sea.

One of the most important differences between the two subspecies is the presence of four spines on the merus of pereiopod 2 in D. enigmatica enigmatica, whereas no spine was found in all developmental stages of both sexes from D. enigmatica rossensis (Table 1). The number of cuspidate setae on first and second articles of the uropodal endopod of the subadult female of $D$. enigmatica enigmatica is five and four, respectively. The number of setae in $D$. enigmatica rossensis is three for both articles in subadult and adult females. The subadult male has tree and four setae which are still less than in D. enigmatica enigmatica. In contrast to D. enigmatica enigmatica, there is a gap between the spines of the peduncle article 1 of the first antenna in $D$. enigmatica rossensis. Additionally, the number of articles of the first antennas flagella of specimens from the Weddell Sea is less than in most even less developed stages of specimens from the Ross Sea (compare Table 1). Further 
Table 1 Differences observed in Diastylis enigmatica between the Weddell Sea and the Ross Sea and between different developmental stages

\begin{tabular}{|c|c|c|c|c|c|c|c|c|c|}
\hline & $\begin{array}{l}\mathrm{sa}+ \\
\text { Weddell Sea }\end{array}$ & $\begin{array}{l}\text { juv } \widehat{o} \\
\text { Weddell Sea }\end{array}$ & $\begin{array}{l}\stackrel{+}{\text { Ross Sea }} \\
\text { Ros }\end{array}$ & $\begin{array}{l}\mathrm{sa}+ \\
\text { Ross Sea }\end{array}$ & $\begin{array}{l}\text { sa } \hat{o} \\
\text { Ross Sea }\end{array}$ & $\begin{array}{l}\text { juv }{ }_{+}^{\mathrm{c}} \\
\text { Ross Sea }\end{array}$ & $\begin{array}{l}\text { juv } \text { q }^{\mathrm{d}} \\
\text { Ross Sea }\end{array}$ & $\begin{array}{l}\text { juv } \text { व }^{\mathrm{c}} \\
\text { Ross Sea }\end{array}$ & $\begin{array}{l}\text { juv } \text { वर }^{\mathrm{d}} \\
\text { Ross Sea }\end{array}$ \\
\hline R UP to last pleon segment & 2.2 & $?$ & 3.1 & 2.8 & 2.8 & 2.7 & 2.3 & 2.9 & 2.9 \\
\hline R UP to exopod & 2.3 & $?$ & 2.7 & $?$ & 2.1 & 1.9 & 1.8 & 2.1 & 1.8 \\
\hline $\mathrm{R}$ postanal to preanal part of telson & $\sim 1.2$ & $\sim 1^{\mathrm{e}}$ & 1.9 & 1.4 & 2.0 & 1.3 & 1.2 & 1.4 & 1.4 \\
\hline $\mathrm{R}$ distal to proximal part of $\mathrm{P} 1$ & 1.0 & 1.2 & 1.3 & 1.2 & 1.2 & 1.3 & 1.2 & 1.1 & 1.1 \\
\hline Setation of endopod of Uropod & $5 / 4 / ?$ & $?$ & $3 / 3 / 4$ & $3 / 3 / 4$ & $3 / 4 / 4$ & $3 / 3 / 3$ & $2 / 2 / 2$ & $3 / 3 / 3$ & $2 / 2 / 3$ \\
\hline Number of spines ${ }^{\mathrm{f}}$ on basis of Mp3 & 5 & 3 & 4 & 4 & 5 & 3 & 2 & 5 & 3 \\
\hline Number of spines on merus of $\mathrm{P} 2$ & 4 & 0 & 0 & 0 & 0 & 0 & 0 & 0 & 0 \\
\hline Number of spines on Ped of A1 & 3 & $?$ & 3 & 3 & 7 & 3 & 2 & 3 & $?$ \\
\hline Gap between spines on Ped of A1 & No & $?$ & Yes & Yes & No & Yes & Yes & Yes & Yes \\
\hline Number of articles of MF/AF of A1 & $3 / 3$ & $?$ & $6 / 4$ & $6 / 4$ & $6 / 4$ & $5 / 3$ & $4 / 3$ & $4 / 3$ & $3 / 3$ \\
\hline
\end{tabular}

Al antenna 1, $A F$ accessory flagellum, $M F$ main flagellum, $M p$ maxilliped, dent denticulate, $j u v$ juvenile, $P$ pereiopod, $P e d$ peduncle, $R$ ratio, $s a$ subadult, UP uropodal peduncle; Data from the Ross Sea obtained from one specimen ( $\left(+\right.$, sa $\hat{\delta}$, juv ${ }_{+}$), three specimens (sa $\odot$ ), or four specimens (juv $\bigcirc_{+}^{\mathrm{c}}$, juv $\hat{\jmath}$ ). Italic characters serve to differentiate the two subspecies of $D$. enigmatica

a Petrescu and Wittmann (2003)

b Ledoyer (1993)

c Older stage than in Ledoyer (1993)

${ }^{d}$ Same stage as in Ledoyer (1993)

${ }^{\mathrm{e}}$ The drawing of the original description differs to the text, in which the postanal part is three times longer than the preanal part

f The maximum number observed is given, but may be less as the spines seem to be broken off or not developed (numbers may vary in the same specimen)

characteristics which also support splitting D. enigmatica into two subspecies are differences in the ratios of "uropodal peduncle to last pleon segment" and "distal to proximal part of pereiopod 1". The subadult female of D. enigmatica enigmatica has five spines on the basis of maxilliped 3; only four spines were recorded in adult and subadult females of D. enigmatica rossensis. As these spines tend to break off, this characteristic has to be treated carefully, even though in some specimens it seemed that no spine has broken off.

Cryptic speciation and the possible effects on the status of the subspecies of Diastylis enigmatica

In the early stage of Antarctic exploration many benthic invertebrates were described to be widespread distributed on the continental shelf surrounding Antarctica. Thus, circumantarctic distribution was assumed for many invertebrate taxa (Hedgpeth 1970; White 1984; Clarke and Crame 1989; Arntz et al. 1994; Dayton et al. 1994). During the last decade, however, cryptic species of several benthic invertebrate taxa in the Antarctic were discovered (Bernardi and Goswami 1997; Allcock et al. 1997; Raupach and Wägele 2006; Linse et al. 2007; Wilson et al. 2007). These findings point towards a higher species richness on the Antarctic shelf than formerly believed.

The genetic variability of the mitochondrial $16 \mathrm{~S}$ ribosomal RNA gene gave first evidence for cryptic speciation in the Antarctic isopods Glyptonotus antarcticus Eights, (1852) and Ceratoserolis trilobitoides, Eights, (1833) (Held and Wägele 2005, Held 2003). Ceratoserolis trilobitoides was regarded as a single species with high morphological plasticity (Wägele 1986), but genetic and morphological data support a scenario of cryptic speciation with more than one species (Held and Wägele 2005). Also, the study of the Ross Sea cumacean fauna revealed minor morphological differences in some of the cumacean species to the original descriptions (Rehm et al. 2007). For the species Diastylis enigmatica these differences are interpreted as differences between subspecies, but future genetic analysis might show that genetic diversity is higher than would be expected to be intraspecific. First results from the examination of $16 \mathrm{~S}$ rDNA sequences of the Antarctic cumacean species Leucon antarcticus Zimmer, 1907 have shown that populations from the Ross Sea and the Weddell Sea have been genetically separated for an extended period of time (Rehm 2007). This is a first indication for cryptic speciation in cumacean species based on molecular methods.

All Antarctic benthic invertebrate species which turned out to consist of a complex of cryptic species have a limited dispersal potential in common. In contrast, decapods with a broadcasting reproduction mode through planktotrophic larvae show a circumantarctic distribution (Rehm 2007). Peracarid crustaceans display brood protection and release their young as mancae, which results in a reduced dispersal potential and might lead to reduced gene flow. As isopods 
and cumaceans belong to the peracarid crustaceans they possibly exhibit similar speciation patterns. In that case it would be very likely that the two subspecies of Diastylis enigmatica are separate species.

Acknowledgments I am very grateful to Maya Robert for the translation of the original description of Diastylis enigmatica from French to English, to Ute Mühlenhardt-Siegel for her advice during the description, to Anna Kop and Sally Hall for their revision of the English, and to Sven Thatje and Christoph Held for reviewing the manuscript. Special thanks are due to Daniel Roccatagliata for his critical annotations and for discussing taxonomic problems, which arose during preparation of the manuscript.

\section{References}

Allcock AL, Brierley AS, Thorpe JP, Rodhouse PG (1997) Restricted gene flow and evolutionary divergence between geographically separated populations of the Antarctic octopus Pareledone turqueti. Mar Biol 129:97-102

Arntz WE, Ernst W, Hempel I (1990) The expedition ANTARKTIS VII/4 (EPOS leg3) and VII/5 of RV "Polarstern" in 1989. Ber Polarfor 68:1-214

Arntz WE, Brey T, Gallardo VA (1994) Antarctic zoobenthos. Oceanogr Mar Biol Ann Rev 32:241-304

Bernardi G, Goswami U (1997) Molecular evidence for cryptic species among the Antarctic fish Trematomus bernachii and Trematomus hansoni. Antarctic Sci 9:381-385

Clarke A, Crame JA (1989) The origin of the Southern Ocean marine fauna. In: Crame JA (ed) Origins and evolution of the Antarctic Biota. Geological Society of London Special Publication. 47. The Geological Society, London, pp 253-268

Coleman CO (2003) "Digital inking": How to make perfect line drawings on computers. Org Divers Evol 14 (Electr. Suppl.):1-14. (http://senckenberg.de/odes/03-14.htm)

Coleman CO (2006) Substituting time-consuming pencil drawings in arthropod taxonomy using stacks of digital photographs. Zootaxa 1360:61-68

Dayton PK, Mordida BJ, Bacon F (1994) Polar marine communities. Am Zool 34:90-99

Hedgpeth JW (1970) Marine biogeography of the Antarctic regions. In: Holdgate MW (ed) Antarctic Ecology 1. Academic Press, London, pp 97-104

Held C (2003) Molecular evidence for cryptic speciation within the widespread Antarctic crustacean Ceratoserolis trilobitoides (Crustacea, Isopoda). In: Huiskes AH, Gieskes WW, Rozema J,
Schorno RM, van der Vies SM, Wolff WJ (eds) Antarctic biology in a global context. Backhuys Publishers, Leiden, pp 135-139

Held C, Wägele J-W (2005) Cryptic speciation in the giant Antarctic isopod Glyptonotus antarcticus (Isopoda: Valvifera: Chaetiliidae). Sci Mar 69(Suppl 2):175-181

Ledoyer M (1993) Cumacea (Crustacea) de la campagne EPOS 3du R.V. Polarstern en mer de Weddell, Antarctique. J Nat Hist 27:1041-1096

Linse K, Copet T, Lorz A-N, Sands C (2007) Is the Scotia Sea a centre of Antarctic marine diversification? Some evidence of cryptic speciation in the circum-Antarctic bivalve Lissarca notorcadensis (Arcoidea: Philobryidae). Polar Biol 30:1059-1068

Mühlenhardt-Siegel U (2005) New species of the family Nannastacidae (Crustacea: Peracarida: Cumacea) from the Angola Basin, south-eastern Atlantic. Deep-Sea Expedition DIVA-1. Addendum. Mitt hamb zool Mus Inst 102:85-97

Petrescu I, Wittmann K (2003) Elements for a revision and notes on bionomy of the Cumacea (Crustacea: Peracarida) of the Weddell Sea (Antarctica). Material collected by the expedition ANTARKTIS-VIII/5 of R.V. "Polarstern" 1998/90. Zool Med Leiden 77:557-630

Raupach MJ, Wägele J-W (2006) Distinguishing cryptic species in Antarctic Asellota (Crustacea: Isopoda) - a preliminary study of mitochondrial DNA in Acanthaspidia drygalskii. Antarctic Sci 18:191-198

Rehm P, Thatje S, Arntz WE, Brandt A, Heilmayer O (2006) Distribution and composition of macrozoobenthic communities along a VictoriaLand Transect (Ross Sea, Antarctica). Polar Biol 29:782-790

Rehm P (2007) Cumacea (Crustacea; Peracarida) of the Antarctic shelf - diversity, biogeography, and phylogeny. Faculty 2 (Biology Chemistry) University of Bremen. http://nbn-resolving.de/ urn:nbn:de:gbv:46-diss000109173

Rehm P, Thatje S, Mühlenhardt-Siegel U, Brandt A (2007) Composition and distribution of the peracarid crustacean fauna along a latitudinal transect off Victoria Land (Ross Sea, Antarctica) with special emphasis on the Cumacea. Polar Biol 30:871-881

Wägele J-W (1986) Polymorphism and distribution of Ceratoserolis trilobitoides (Eights, 1833) (Crustacea, Isopoda) in the Weddell Sea and synonymy with C. cornuta (Studer, 1879). Polar Biol 6:127-137

White MG (1984) Marine benthos. In: Laws RM (ed) Antarctic ecology, vol 2. Academic Press, London, pp 421-461

Wilson NG, Hunter RL, Lockhart SJ, Halanych KM (2007) Multiple lineages and absence of panmixia in the "circumpolar" crinoid Promachocrinus kerguelensis from the Atlantic sector of Antarctica. Mar Biol 1152:895-904

Zimmer C (1907) Neue Cumaceen aus den Familien Diastylidae und Leuconidae von der Deutschen und Schwedischen SüdpolarExpedition. Zool Anz 31:220-229 